\title{
Ireland in the Atlantic World: Migration and Cultural Transfer
}

\author{
WILLIAM O’REILLY
}

In Mexico City in 1641, a befreckled, redheaded Irishman hatched a plan to make himself king of New Spain and free the land from tyrannical rule. William Lamport, born thirty years earlier in Wexford, had reinvented himself as the Spanish nobleman Don Guillén de Lombardo, a soldier of fortune, ambitious adventurer and at times crazed visionary, who would, in 1659, be burned at the stake after the failure of his brooding attempts to establish himself as the legitimate heir to Philip III. The Irishman's attempts to install himself as a monarch to rule a kingdom in which, he proclaimed, African slaves, castas, mulattos and Native Americans would be free and granted the same liberties as whites, and where commerce and trade with Spain's old enemies would be opened up, is representative of the scale of opportunities open to Irish immigrants in the early modern Atlantic world. Like many economic, social, religious, political refugees and migrants from Ireland, Lamport, together with his sister and two brothers, left Ireland and travelled first to the European continent: his sister Catherine found a new life as a nun, his older sibling John became a Franciscan friar and Gerald, his younger brother, a mercenary. William travelled from Ireland to France, where he connected with long-established Irish trade networks, and further to Spain, where again he relied on the support of the large and well-respected Irish community. Lamport joined the other españoles del norte and attended the Irish College at Santiago de Compostela, before moving on to Lorenzo College at the Escorial. He crossed the Alps and fought in the army of Philip IV at Nördlingen in July 1634 , and appeared again, together with his brother Gerald, as a soldier in the Basque country in 1638. Embroiled in a scandal when he refused to marry the well-born woman with whom he formed a household, 'Don Guillén' left Spain in 1640, crossing the Atlantic for New Spain, possibly under the patronage of the Count-Duke Olivares. In Mexico, the adventurer and opportunist 
grew in confidence, building on his many experiences. ${ }^{1}$ Claiming to be the half brother of Philip IV of Spain, Lamport's ultimate fate - denounced as a magician, an astrologer and a Protestant, spending seventeen years in an Inquisition gaol - was that he was paraded through the thronged streets of Mexico City on the way to an auto de fé, burned alive for heresy and sedition. ${ }^{2}$

It is likely that William Lamport knew all too well of his real ancestry and knew, too, that in the long-established tradition of ousting kings, claiming royal blood bestowed on the pretender at very least a veneer of legitimacy. And Lamport knew, too, that only with the popular support of the majority in this case, of slaves, castas and mulattos - would he stand any chance of success. And perhaps the Irishman could have succeeded; that he did not is only less impressive than that he felt he might. Lamport had spent his life avoiding monarchical rule in Ireland, serving another sovereign abroad, before rejecting that rule, too, in favour of a self-serving utopianism built of his experiences in Ireland, France, Germany, Spain and New Spain. His story is exceptional, of course, yet it goes some way to show the range of possibilities open to pre-nineteenth-century Irish migrants in the Atlantic world.

For much of its history, the Irish in the Atlantic world, or even the notion of an 'Irish Atlantic' in the period before the age of steam, has been portrayed as little more than the trade in indentured servants, with Irish emigration to continental Europe represented as a distinct historiography and a distinctive feature of life-in-exile for a Catholic middling sort who found service and opportunities at court and in academic, administrative, mercantile, military and religious service in Madrid, Paris, Vienna, Prague and satellite cities in Catholic Europe. Irish migration into the Atlantic sea, and resettlement throughout the Americas, has been seen as a secondary result of the primary necessity to leave Ireland, largely for reasons of religious persecution and dispossession. Undoubtedly, a large number of Irish people were forcibly removed from the country in the mid-seventeenth century, and still more were subject to a punitive colonising economic system which strong-armed the able into accepting there was little chance of improvement at home, and thus created an outflow of literate and skilled men, and some women, in search of a better life. Yet it would be both misleading and simply wrong

1 S. Kline, 'William Lamport/Guillén de Lombardo (1611-1659)', in Karen Racine and Beatriz G. Mamigonian (eds.), The Human Tradition in the Atlantic World, 1500-1850 (Plymouth: Rowman \& Littlefield, 2010), 43-56.

2 R. D. Crewe, 'Brave New Spain: An Irishman's Independence Plot in Seventeenth Century Mexico’, Past \& Present, 207 (2010), 53-87. 
to represent the Irish in the Atlantic as a diasporic community. This was no classic uprooted migration narrative, certainly not before the nineteenth century, and cultural life and religious practice continued unabated, whatever the challenges. ${ }^{3}$ Rather, Irish involvement in the Atlantic world was an activated option for the majority involved: men and women joined an international labour market - in commerce, in social and religious care, in education, in soldiering, in manual labour - which saw them fare well in some contexts, thrive and excel in others, and which saw most serve, and a few claim to be, kings. Irish identity in the pre-famine Atlantic world was built more on contemporary aspirations for betterment and improvement than it was on exile and persecution, watchwords of a later cultural-political nationalism which placed emphasis, post-hoc, on the overarching feature of commonality shared by the majority, their confessional identity. This is not to say that dreams of a different Ireland did not exist: powerful poetry provides evidence of that; albeit, the greater part of that corpus seeks to displace one foreign king for another. Yet 'no collective identity... is static' and any sense of identity in the pre-modern period was both 'place-specific and time specific'. ${ }^{4}$ Jack Greene identifies four parts of a collective self-image in this age before mass print and media: the sense of place, the identification of goals, the insistence on standards and the sense of history. ${ }^{5}$ On these terms, and considering the Irish in the Atlantic world, there were no shared goals and standards whatever about a shared place of origin and a shared history - albeit in Ireland that history was, at one and the same time, being repressed, repackaged and rewritten. There was no 'Irish' press in the Atlantic world beyond Ireland, and certainly not in the Irish language; this absence may have held up the process of identity formation, as it did in other parts of the Atlantic. ${ }^{6}$ Attempts to position Ireland as an island polity ancient and true continued, but these efforts were roundly attacked and squarely upended by an English-language community retailing a different antiquarian political genealogy. ${ }^{7}$ In 1625, the Irish historian Philip

3 O. Handlin, The Uprooted. The Epic Story of the Great Migrations that made the American People (Philadelphia: The University of Pennsylvania Press, 2002), 2nd edn.

4 An analysis of its changing content reveals, perhaps as well as can the study of any other single phenomenon, the character of a given colony's responses to the successive social, economic, cultural, and political transformations it underwent' N. Canny and A. Pagden (eds.), Colonial Identity in the Atlantic World, 1500-1800 (Princeton: Princeton University Press, 1987), 8.

5 Canny and Pagden (eds.), Colonial Identity in the Atlantic World, 9.

6 As in, for example, Brazil; Canny and Pagden (eds.), Colonial Identity in the Atlantic World, 12.

7 C. O’Halloran, Golden Ages and Barbarous Nations. Antiquarian Debate and Cultural Politics in Ireland, c.1750-1800 (Cork University Press, 2004), especially 'Phoenicians and Goths', 41-70 and 'Irish Custom, Law and Lawlessness', 127-40. 
O’Sullivan Beare concentrated entirely upon countering Cambrensis and all those who were relying on him for their views of the country: 'Ireland is not deserted, without roads, and boggy, as Cambrensis would have it, but is heaped with glory under many headings. ${ }^{8}$ Yet while Cambrensis's writings were widely circulated in the sixteenth century, with the antiquarian William Camden publishing a further edition in 1602, O’Sullivan Beare's refutation was not published in his own lifetime; the circulated views of Ireland were not necessarily those captured with Irish eyes. The cultural élite of an emerging Anglo-Irish community grew to denigrate the contemporary Gaelic nation as barbaric and benighted. ${ }^{9}$ The unequal power relations which silenced the perspective of the majority disallowed a canonical reading of Irish identity, at home as abroad. ${ }^{10}$ In the Atlantic world, the Irish were more like the Scots, perhaps the Dutch, than the Sephardic Jewish diaspora or the Huguenots. This was an Irish international, not an Irish diaspora.

\section{Ireland in the Atlantic sea}

Long before Irish settlement in the Americas, magical and invisible things were known to inhabit the Celtic world of the Atlantic coast of Europe. The Irish, as in the Leabhar Gabhála, knew of three routes which brought people to their island: in the east, from the European continent and across St George's Channel; in the south, from the near Atlantic and Hispania; and in the north, from Scandinavia and the Baltic. ${ }^{11}$ No mention was made of a route from the west, where Hy Brasil, and Tír na nÓg and eternal youth were to be found. Nor did the Irish refer to the 'Atlantic', but rather to 'Talamh an Éisc' and later 'Newland' and 'New England'. ${ }^{12}$ Irish and English activities in the near Atlantic changed, in the fifteenth century, when the rising Hanseatic League began to exclude foreigners from the profitable market in the Baltic;

8 Philip O'Sullivan Beare, Vindiciae Hibernicae contra Giraldum Cambrensem et alios vel Zoilomastigis (Cork University Press, 2009), Book One, 267.

9 C. Kidd, British Identities before Nationalism: Ethnicity and Nationhood in the Atlantic World, 1600-1800 (Cambridge University Press, 1999), 181.

10 A. Horning, 'Challenging Colonial Equations? The Gaelic Experience in Early Modern Ireland', in N. Ferris, R. Harrison and M. V. Wilcox (eds.), Rethinking Colonial Pasts through Archaeology (Oxford University Press, 2014), 297.

11 R. Sainero, The Celts and Historical and Cultural Origins of Atlantic Europe (Palo Alto, CA: Academica Press, 2013), 131.

12 Aogán Ó Rathaille, 'Tairngreacht Dhoinn Firínne' used 'Newlan'; in 'Carraig Seac', writing: 'Chuaigh scéal ar an mbualadh thar na tonnta taosach/go Talamh an Éisc agus go Sasana Nua'. Aogán Ó Rathaille, ed. B. Ó Buachalla (Baile Átha Cliath: Field Day Publications, 2007), 33; D. Ó hÓgáin, Dunaire Osraíoch (Baile Átha Cliath: An Clóchomhar, 1980), 42. 
fishermen were driven to look elsewhere for fish stocks, and the place they chose was Iceland. ${ }^{13}$ Knowledge of the routes between Ireland and the North Atlantic increased, as a result, and with them claims to ownership of territories 'discovered'. Accounts of the early Christian missionary Brendan of Ardfert and Clonfert (c.484-580), 'the Navigator', in the Navigatio sancti Brendani Abbatis, tell of the monk's journeys over the sea towards the west, sailing for seven years before eventually finding 'the Promised Land, which God will give to those who come after us at the end of time'. Some writers reached antiquarian heights in efforts to have Brendan visit Mexican shores so that he became the Aztec Quetzalcoatl; the white-skinned and bearded figure who promised to return was Brendan. ${ }^{14}$ Wherever he may have sailed, if at all, his account was used in the later sixteenth century by the Tudor apologist John Dee as evidence for Elizabeth I's claim to northern lands and the New World. Whether Brendan reached Newfoundland in c.550 or not, the actions of the ancients in Ireland granted, by precedent, Dee's new 'British empire' jurisdiction over all that lay to Ireland's west.

In the fifteenth and sixteenth centuries, Irish activity in the Atlantic ocean was largely a west-of-Ireland venture, with vessels setting sail near-exclusively from the port of Galway. Fishing and whaling were well established off the Irish coast and even Ottoman maps of the early sixteenth century describe the activity; by the early eighteenth century, whale and shark oil lit lamps from Donegal to Galway. ${ }^{15}$ Domestic cartography, shipbuilding and exploration was certainly underdeveloped when compared with continental European neighbours, and much Irish Atlantic activity resembled littoral hop-scotch, skimming from port to port; from Iberia to southern England to southern and western Ireland. Trade with northern Spain thrived in the fifteenth century; much of it was in the hands of Basque shippers who, working from Santander, Bilbao and other smaller ports in the region, traded northward to Ireland. ${ }^{16}$ And Irish goods and people went in the opposite direction, too. Penitents frequently made the journey to Santiago de Compostella, venerating the shrine of St James. For pilgrims from Ireland all the major ports - from Dublin in the east to Galway in the west - provided ships, as did the ships of

13 B. Cunliffe, Facing the Ocean: The Atlantic and its People, 8000 BC-AD 1500 (Oxford University Press, 2001), 539.

14 G. A. Little, Brendan the Navigator: An Interpretation (Dublin: Gill, 1945).

15 See A. Afetinan, Life and Works of Piri Reis: The Oldest Map of America (2nd edn., Ankara: Turkish Historical Society 1987); A. E. J. Went and S O Súilleabháin, 'Fishing for the Sun-Fish or Basking Shark in Irish Waters', Proceedings of the Royal Irish Academy, 65:C (1966-1967), 91-115.

16 Cunliffe, Facing the Ocean, 534-5. 
Bristol, sometimes stopping at Plymouth en route, and carrying as many as a hundred pilgrims at a time. ${ }^{17}$ Irish engagement with Spain and Portugal continued throughout the fifteenth and sixteenth centuries, and substantial Irish confraternities existed in Seville and elsewhere. ${ }^{18}$ Irish mariners manned ships for Spain and Portugal, and served aboard vessels sailing in and out of the Mediterranean; Irish corsairs were active in privateering and piracy outfits in the near Atlantic. The great pirate queen Gráinne O’Malley journeyed from Clew Bay in 1593 to meet Elizabeth I. As shown by the strength of evidence from France and Spain of large confraternities, Irish mercantile families were scattered around the Atlantic and beyond, benefiting from their position on the western-most coast of Europe and on the tightrope of Dee's emerging empire.

Undoubtedly, distinct cultural institutions and geographical location worked to the advantage of the Irish in the Atlantic and these factors were exploited. Like the Scots in their Atlantic activities, the Irish grew in ingenious ways in this Atlantic world, learning to overcome the later mercantilist system within the seventeenth- and eighteenth-century Navigation Acts. Ireland would become a centre for a provision trade based in Cork which exported supplies and victualled slave plantations and coastal American ports; for a burgeoning linen trade centred in Belfast which exported to all parts of the Atlantic world and for a west-coast trade in butter, salt fish and migrants. A native landed gentry may have been missing in rural Ireland, especially from the start of the seventeenth century, but this did not stop the growth of Dublin as the commercial centre for the island, or the rise of Irish networks throughout the Atlantic and beyond. Not unlike the Dutch, the Irish in the Atlantic world were connected by the ocean, and not divided by it.

\section{Ireland and Latin America}

As already described, by the sixteenth century Ireland's contacts with the Iberian peninsula were well established and flourishing. Trade and communication were frequent and, perhaps most signal in this regard, trade between the Canary islands and the Iberian peninsula brought the merchant Christopher Columbus to Galway in 1477; one William Eris, or Ayres, a native of the city, is remembered as a member of the voyage of 1492, one of the

17 Cunliffe, Facing the Ocean, 534-5.

18 K. Schüller,DieBeziehungenzwischen Spanien und Irlandim 16. und17.Jahrhundert:Diplomatie, Handel und die Soziale Integration Katholischer Exulanten (Münster: Aschendorff, 1999). 
forty volunteers remaining behind on Hispaniola in December that year. Another three Galway sailors sailed with Ferdinand Magellan on his circumnavigation in 1519-1522.

What did change in the course of the sixteenth century, however, was as a consequence of growing English involvement in the political life of Ireland and of confessional conflict. Members of Ireland's Old English families began to withdraw their sons from the universities of Oxford and Cambridge, choosing instead to send them to Catholic universities in continental Europe. Influenced by the zealous spirit of Counter-Reformation Catholicism, they were involved in the establishment of a number of Irish Colleges, notably in Alcalá de Henares, Santiago de Compostela, Seville, Madrid, Paris, Lisbon and Salamanca. The opening of the Real Colegió de San Patricio de Nobles Irlandeses in Salamanca in 1592 gave Irish students their largest base on the continent; a royal annuity and a viaticum of $£ 10$ for each student who finished his course and returned to Ireland meant that students were secure in their studies and could go on to play important roles in religious, military and administrative life in Spanish service in the Americas. ${ }^{19}$ With Salamanca in particular, Irish and Old English families had a base for émigré religious, military and commercial migrants, even before Kinsale (1601). Contacts with Portugal and Spain certainly precede Salamanca and the confraternidades in Seville and Cádiz, but they attained quasi-plenipotentiary rights in the form of the Salamanca College which appeared, to many, as having the status of an extra-territorial mission.

It was through their contacts with Catholic Europe, and most especially Spain, that Irish men and women began to cross the Atlantic, working as soldiers, missionaries and labourers. Franciscans and Jesuits, from Ireland and of Irish heritage, served in Spanish and Portuguese stations and were seen to have an advantage over their Iberian coreligionists; as missionaries they could speak English and therefore counter the work of Dutch and English colonisers whom they might encounter abroad. Juan and Tomás Farel (Farrell) were in the 1536 expedition of Pedro de Mendoza to the River Plate, and they went on to found and settle Buenos Aires. One early missionary active in Latin America was Limerick-born Thomas Field (1547-1626) who, three years after joining the Society of Jesus in Rome, arrived in Spanish Brazil in 1577. After spending three years in Piratininga (São Paulo), he continued to Paraguay and proselytised among the Guaraní people. Field is most likely the first Irish-born cleric to have engaged in a mission in the Americas. He died in Ascunción, at the centre

19 M. Henchy, 'The Irish College at Salamanca', Studies 70 (1981), 220-27. 
of the 'Giant Province of the Indies' (Provincia Gigante de Indias) in 1626. As with Field, many of the early Irish migrants in the Atlantic served as proxy agents of European imperial ventures: as missionaries, as soldiers, as merchants, planters and colonists in French, Spanish and Portuguese service. Others, as is evident from the records of the Dutch West and East Indies Companies, worked in the service of the United Provinces, in short-lived German ventures to the Caribbean in the early seventeenth century and, of course, in English service. In 1612 for example, James and Philip Purcell negotiated with the Portuguese crown and helped establish a colony at Tauregue named 'Purcell's Creek', at the mouth of the Amazon River; they lived there together with Dutch, English and French settlers. Eight years later they were joined by a dozen settlers from County Clare, led by Bernardo O’Brien, and they built a fortress on the north bank of the Amazon near Macapa, trading in dyes, hardwood and tobacco and having outposts from Cabo do Norte (Amapá) to the equator. The settlers - with family names de Courcy, Moore and Mulryan amongst them - established good terms with the local Tupí Indians and they proved a useful ally for the natives against the Portuguese. O’Brien became expert in navigating the tributaries at the mouth of the Amazon and he was conversant in the local Arruan language; his linguistic and navigational skills helped him make a considerable profit and led to many further migrants from Ireland following in his wake. This Irish colony on the Amazon may be the earliest example of an independent Irish colonial project in the Americas; serving first for the Dutch West India Company, the Irish settlers later petitioned the Spanish crown for a licence to settle the Amazon. Only the restoration of the Portuguese monarchy in 1640 and changing foreign policy interests of the English and others ended this colonial venture. ${ }^{20}$

Early Irish migrants to Latin America were compliant members of the imperial system; only in the later eighteenth century did their descendants become French-inspired republicans and emerge as proxy revolutionaries for their new homelands. Whether in the Portuguese Amazon, in Spanish Mexico, on French Caribbean islands, in Dutch service or working in partnerships based in Bristol or Ireland itself, the Irish in the Atlantic were adroit in forging Atlantic networks not always dependent on English, or indeed other, patrons. Yet while the terms 'Irish', 'Irish nation' and 'Irish Catholics' appear in both English and Spanish archives for this period, in matters of commerce it was felt that wherever the Irish went, they brought in the English. ${ }^{21}$ And it

20 J. Lorimer, English and Irish Settlement on the River Amazon, 1550-1646 (London: Hakluyt Society, 1989).

21 Lorimer (ed.), English and Irish Settlement on the River Amazon, 401-6. 
was in English service and in English territories that the Irish in the Atlantic were most active.

\section{Ireland and the 'Commercialising of Colonisation'}

Ireland was one of only two European countries, together with the Netherlands, which in the early modern period was both a country of immigration as well as emigration. As Nicholas Canny has argued, when it came to the colonisation of its Atlantic colonies both England and the Netherlands relied to a large extent on foreigners. In the first century of English activity in the Americas, more English settlers migrated to Ireland than they did to the Chesapeake. England's experience of Atlantic colonisation relied for, a large part, on Irish and Scots who could, in large numbers, be used to colonise the British West Indies and Chesapeake.

The transatlantic colonial economy also served to expand opportunities for emigration, thereby creating multinational British colonies later in the early modern period. ${ }^{22}$ Colonial migration created avenues of mobility for the Irish and others, denied them within the domestic framework. English state interests were also served through the migration of these cultural groups to the colonies, which enabled the containment of Irish autonomy within the project of British imperialism. ${ }^{23}$ The prospect of colonial settlement provided the opportunity to erase internal divisions, or in the words of Shakespeare's Henry IV, to 'busy giddy minds / With foreign quarrels' (2 Henry IV, 4.5.213-14). Colonial expansion ultimately served to reinforce inequalities between core and peripheral regions, as expanding resources of capital became increasingly centralised in London, a process that marginalised not only Ireland, but also emerging commercial centres like Dublin and Bristol. ${ }^{24}$

Without question, contact with, and experience in, Ireland affected English attitudes towards the Irish in the Atlantic world. The establishment of numerous 'non-trading' Atlantic ventures from the start of the seventeenth century increased the importance of colonial ventures in the portfolios of investors in London and elsewhere. Colonial connections between England and

22 B. Bailyn and P. D. Morgan, 'Introduction', in B. Bailyn and P. D. Morgan (eds.), Strangers within the Realm: Cultural Margins of the First British Empire (Chapel Hill, NC: University of North Carolina Press, 1991), 1-31.

23 M. Netzloff, 'Writing Britain from the Margins: Scottish, Irish, and Welsh Projects for American Colonization', Prose Studies: History, Theory, Criticism, 25 (2002), 3.

24 D. Harris Sacks. The Widening Gate: Bristol and the Atlantic Economy, 1450-1700 (Berkeley, CA: University of California Press, 1991). 
the Americas were stronger by 1613 than at any other point, thanks to the recent growth of the Virginia and Irish Companies, both of which attracted a lot of interest from East India Company (EIC) members. The year 1613 was also the busiest period for the EIC in terms of its own colonial activities; the Company developed three villages in Dundaniel, County Cork, to take advantage of commodity extraction from Ireland, linking Irish trade and commerce at this early stage, albeit in a minor way, to the Indian, and not just Atlantic, ocean. ${ }^{25}$ Attempting to convince settlers to follow him to Ireland, Robert Payne argued that the peacefully inclined Irish were avid readers of Las Casas's tales of Spanish cruelty in the Americas and so were especially keen to accept English rule rather than throw their lot in with the Catholic Iberian empire. ${ }^{26}$ English colonial texts progressively replaced an older chivalric model of adventure with a more commercially minded framework of economic 'ventures', in what has been termed 'the commercialising of colonisation'. This is best demonstrated by the dominance of London-based companies in plantation efforts in Ulster, Virginia and the Caribbean in the first decades of the seventeenth century. ${ }^{27}$

Yet there was an English anxiety concerning the levels of cultural contamination which might take place, were Irish migrants to gain access to English settlements; this can be seen in Spenser's A View of the Present State of Ireland (c.1596) and other texts when describing Englishmen who had become assimilated within Irish culture. ${ }^{28}$ Like Spenser, Henry Cary, Viscount Falkland, associated the threatening possibility of English cultural 'degeneration' with Irish women, prompting him to stipulate that all female immigrants to English colonies should be English, a specification not extended to male colonists: 'then it is noe great matter of wha[t] nation the men bee soe the women bee English' ${ }^{29}$

25 P. O’Sullivan, 'The English East India Company at Dundaniel', Bandon Historical Journal, 4 (1988), 3-15; E. Smith, 'Naval Violence and Trading Privileges in Early SeventeenthCentury Asia', International Journal of Maritime History, 25 (2013), 147-58.

26 Robert Payne, A Briefe Description of Ireland: Made in this yeere, 1589, ed. A. Smith (Dublin: Irish Archaeological Society, 1841); A. Hadfield, 'British Colonial Expansion Westwards: Ireland and America’, in S. Castillo and I. Schweitzer (eds.), A Companion to the Literatures of Colonial America (Oxford: Blackwell Publishing, 2005),196.

27 M. Nerlich, Ideology of Adventure: Studies in Modern Consciousness, 1100-1750, trans. R. Crowley (2 vols., Minneapolis, MN: University of Minnesota Press, 1987), i, 164; C. Shammas, 'English Commercial Development and American Colonization, 15601620', in K. R. Andrews (ed.), The Westward Enterprise: English Activities in Ireland, The Atlantic, and America, 1480-1650 (Detroit, MI: Wayne State University Press, 1979), 151-74.

28 N. Canny, Making Ireland British, 1580-1650 (Oxford University Press, 2001).

29 Falkland, 'To the Well Affected Planters in New Fownde Lande', in G.T. Cell (ed.), Newfoundland Discovered: English Attempts at Colonisation, 1610-1630 (London: Hakluyt Society, 1982), 244-5 (quote at 245). 
Falkland's early seventeenth-century receptiveness to the immigration of Irish men into the English Atlantic world, including Catholics, even while he strictly enforced the religious and national origin of female migrants, might attempt to conceal an effort for forced conversion, a possible hope that male Irish Catholic migrants into the Atlantic colonies would, by default, marry the only (Protestant) women in the colonies, and thereby accept Protestantism. By so doing, Falkland intended to place Protestant English women in the same position of authority over acculturation that Spenser and others had found so threatening when assumed by Irish women. ${ }^{30}$ Falkland's kinsman, Thomas Cary, penned the sole example of a text promoting colonisation, $A$ Short Discourse of the New-found-land (1623), published in Dublin in the early modern period. ${ }^{31}$ In New-found-land he argued that Irish settlement overseas would produce a degree of economic self-sufficiency for Ireland, encouraging Irish manufacture and creating an outlet for Irish goods in the Americas, yet at the same time acknowledging that the ultimate beneficiary of Irish prosperity would be England. ${ }^{32}$ Only later, at the end of the eighteenth century, was Newfoundland a prime site of Irish immigration.

Following Falkland, William Petty continued with this commodification of Irish labour - everything's value could be reduced to the amount of labour it took to produce. ${ }^{33}$ Petty discussed how deaths due to rebellion and unrest in Ireland could be offset by an increase in population in the American plantations. 'Besides it is hoped that New England, where few or no Women are Barren, and most have many Children, and where People live long, and healthfully, hath produced an increase of as many People, as were destroyed in the late Tumults in Ireland. ${ }^{34}$

\section{Ireland, Africa and the Americas}

Most studies of Ireland and the country's contacts with Atlantic Africa, especially southern Africa, begin their story in $1795 .{ }^{35}$ The history is a much older one, however, and it certainly possesses a lengthy chapter on Irish involvement

30 Netzloff, 'Writing Britain from the Margins', 12.

31 Netzloff, 'Writing Britain from the Margins', 12.

32 Netzloff, 'Writing Britain from the Margins', 12.

33 William Petty, 'Treatise of Taxes', in The Economic Writings of Sir William Petty, ed. C. H. Hull (2 vols., Cambridge University Press, 1899), i, 43.

34 William Petty, 'Political Arithmetick', in Economic Writings of Sir William Petty, ed. Hull, i, 303.

35 D. McCracken (ed.), The Irish in southern Africa, 1795-1910 (Durban: Ireland and Southern Africa Project, 1991). 
in the Atlantic slave trade. While the Atlantic crossing from Ireland may have been unpleasant, the rigours of the voyage were hardly comparable to those involved in crossing 'that frightful ocean' in a state of slavery. ${ }^{36}$ The transatlantic voyage was, for Irish migrants, 'the decisive divide of their lives', yet it cannot be compared with the experience of cultural, linguistic and individual isolation that befell the millions of enslaved Africans robbed of freedom. ${ }^{37}$

Irish merchants' exclusion from membership of the slave-trading Royal Africa Company (1660-1752) meant that Ireland was banned from participation in the infamous triangular trade for most of the eighteenth century. Ireland underwrote the slave trade in other ways, however. Goods, including barrelled butter and salt beef for slaves, and spiced salmon and pickled tongue for masters, were exported from Cork to the West Indian plantations. 'Caribbean butter' made the dairy farmers who produced it and the Cork merchants who sold it, some of the wealthiest in the country. And merchants like Henry Blake of Galway amassed a small fortune and lands in Ireland from sugar produced by African slaves. In 1729 alone, the majority of the 5,855 slaves on the Caribbean island of Montserrat were owned by Irish families, including the Farrills (Farrells), Husseys, Lynches, Roaches and others. About one in eight of all sailors (some 12 per cent) aboard slaving ships working out of the port of Liverpool (which accounted for one-third of Europe's trade in enslaved Africans in the eighteenth century) were Irish men - the highest non-English group involved in the trade. Included in this slaving group were the Irish Catholic David Tuohy and the Ulsterman-turned-Antiguan planter Samuel Martin; the latter turned away from slaving only later in life. South from Ireland on the French coast, men of Irish heritage such as Antoine Walsh (1703-1763) were infamous as slave traders; Walsh's ventures made him famous in Nantes and St Malo and he became one of the wealthiest of the many Irish merchants in the French Atlantic slave trade. These Irish merchants, in France, England and the Americas, were directly connected to the Company of Merchants Trading to Africa, the successor to the old Royal African Company: the first governor of the Province of Senegambia appointed in 1756 was one Charles O’Hara, illegitimate son of James, Baron Kilmaine. O’Hara was followed in post by Matthew MacNamara and he by John Clarke; Britain's first formal colony in west Africa was run predominately by Irishmen. ${ }^{38}$

36 Canny and Pagden (eds.), Colonial Identity in the Atlantic world, 4.

37 Canny and Pagden (eds.), Colonial Identity in the Atlantic world, 7.

38 J. D. Newton, 'Naval Power and the Province of Senegambia, 1758-1779', Journal for Maritime Research, 15:2 (2013), 129-47. 
While African slavery and slaves were rare in Ireland, there is evidence of slaving ships operating out of Dublin. Despite having failed twice at establishing slaving companies later in the eighteenth century (at Limerick in 1784 and Belfast in 1786), Irish merchants were very active in supplying slave plantations in the Caribbean. Newspapers in Cork and Dublin very occasionally carried advertisements of slaves for sale and notices of runaways, and one Samuel Burke, a South Carolinian 'Irish-speaking negro', was identified as a resident of Cork. ${ }^{39}$ How much of the wealth made in the slave trade made its way into Ireland? It is difficult to know; just as difficult, perhaps, as to ascertain how 'Irish' the merchants involved in the trade in Antigua, Liverpool or St Malo felt, or what level of unease - if at all - they felt in dispossessing and degrading other peoples while themselves dispossessed. When the Slave Compensation Commission began recompensing slave holders for their 'lost property' in 1834, it was an Irishman, James Blair of Newry, who collected the largest single sum in the British Empire, owing over 1,500 slaves. At best, many Irish slavers and slave owners were creole Irish; at worse, they learned lessons from their neighbours, gaining advantage from the slave trade. In this way, perhaps, they belonged to that class already seen in late sixteenth-century Ireland by Laoiseach Mac an Bhaird when he wrote, 'A fhir ghlacas an ghalldacht' ('O man who follows English ways'). ${ }^{40}$

\section{Ireland and the Caribbean}

Arriving, disappearing and re-emerging in different forms, the Irish have been a changing but constant presence in the history of the Caribbean. Of all the areas of Irish settlement in the early modern Atlantic, the preferred destination for the Irish was the island of St Christopher, whose founder and governor, Sir Thomas Warner, was himself an adventurer from an earlier settlement in Guyana. From 'St Kitts', the Irish made their way to nearby islands including Antigua, Montserrat and Nevis. Montserrat, a 'noble plantation of Irish Catholiques' (1634) was in 1668 described as 'almost an Irish colony' that had been created by Catholic Irishmen who had fled Virginia because 'the Virginians would not suffer to live with them'. ${ }^{41}$ By 1639 there were some 3,000 Irish Catholics living on the Leeward islands.

391762 and 1768, respectively. N. Rodgers, Ireland, Slavery and Anti-Slavery: 1612-1865 (London: Palgrave Macmillan, 2007), 33.

40 D. Greene and F. Kelly (eds.), Irish Bardic Poetry: Texts and Translations, Together with an Introductory Lecture by Osborn Bergin (Dublin Institute for Advanced Studies, 1970, repr. 1984), 49-50, 231-2.

41 K. Block and J. Shaw, 'Subjects without an Empire: The Irish in the Early Modern Caribbean’, Past \& Present, 210 (2011), 35, n. 7. 
An Irish presence was not limited to these islands. The soldier of fortune John Murphy Fitzgerald Burke, 'Don Morfo Geraldino y Burco', who described himself as a noble from Galway, established a real presence on Hispaniola. Using his Irishness as a passport to Spanish employment and deserting the French and English buccaneers of Tortuga, he led a Spanish raid on the island and later, in 1655, Don Murfo successfully led the Spanish forces from Hispaniola against Cromwell's Western Design. ${ }^{42}$

In French service in the western Atlantic, the Irish played a crucial role in gaining Montserrat and parts of St Christopher from England and for France in 1666. Although in later negotiations the islands were returned to England and the Irish Protestant governor of Montserrat, Anthony Briskett, was relieved of his position, he was replaced by an Irish Catholic governor, William Stapleton, because it was felt he would 'understand how to govern his countrymen'. By the 1670s, Stapleton had amassed governorships of all the English Leeward islands. ${ }^{43}$ From an Old English Tipperary family, Stapleton was both a soldier and crown loyalist - a Catholic who built two parish churches on the island while also securing the services of the first resident Anglican clergyman - and the husband of a well-established English heiress to the largest English estate on the island of Nevis. Stapleton never took the required oaths of allegiance and supremacy, although he enthusiastically reaffirmed his loyalty to the crown and took every opportunity to underscore his unwavering record of support for Charles II. Urging fellow Irish men on Montserrat to do likewise, under Stapleton's tenure Irish Catholics on Montserrat rose to positions as elected assemblymen and came to hold numerous positions of importance. ${ }^{44}$ Under his instruction an island census was taken in 1678 and it unusually recorded 'nationality': 69 per cent of whites were recorded as 'Irish'. Yet Montserrat was no Irish colony: English planters like John Wyke always dominated, albeit only with the support of Protestant Irish families like Parsons (Laois/Offaly) and Frye (Limerick). Irish Catholics who did well, from Connacht and Munster, formed a middling-class of traders and planters, whose position on the social ladder was elevated predominately because they stood on the backs of African slaves.

By 1690 in the Caribbean, Governor Christopher Codrington feared that Irish Catholics would follow the example set by those on St Christopher and

42 N. Rodgers, 'A Changing Presence. The Irish in the Caribbean in the Seventeenth and Eighteenth Centuries', in A. Donnell, M. McGarrity and E. O'Callaghan (eds.), Caribbean Irish Connections: Interdisciplinary Perspectives (Kingston, Jamaica: The University of the West Indies Press, 2015), 20.

43 A. Burns, History of the British West Indies (New York: Barnes and Noble, 1965), 342.

44 Rodgers, 'A Changing Presence', 20. 
would declare for King James, or worse would arm the slaves and rise up with them, as was rumoured to have happened on Barbados ${ }^{45}$ Even after authority was restored, Codrington feared the Irish would cross the colour line, or at least make it less diametric. At times, Irish settlers in the Caribbean may have seemed less white than their English overlords, but they were never subject to the same levels of colour prejudice that damned labourers of African heritage. ${ }^{46}$

Irish servants who remained on Barbados mixed with English people of similar social status, lost their distinctive Irish language, accent and Catholicism, and became 'poor whites'. Once the servant class disappeared, the largest number of Irish-speakers was to be found among the sailors; only on Montserrat did a few words of Irish make their way into the quotidian English patois used by all. As long as slavery lasted they enjoyed certain privileges as 'military tenants', supplied with small plots of land to enable them to man the militia. As time moved on, they seem to have been ever less aware of their Irish roots, and almost certainly held no developed sense of an Irish identity before the late eighteenth century, at earliest. The many descendants of white Irish-slave relationships were certainly unaware of any sense of belonging to the Irish nation.

\section{Ireland, North America and Emigration}

Migration from Ireland into the Atlantic world before the mid-eighteenth century can be distinguished by magnitude and destination associated with two consecutive episodes: the first, from small-scale emigration in the sixteenth and early seventeenth centuries, which was not always directly from Ireland, down to the end of the 1670s; and the second, from the establishment of Pennsylvania until the later eighteenth century. In the very early 1600 s, Irish emigration to North America was negligible and consisted primarily of unmarried, Catholic males, but by the end of the 1600s, some 100,000 Irish emigrants had made their way to North American and Caribbean colonies. On the American mainland, the first documentary record of Irish inhabitants of Newfoundland comes from 1622; four decades later in 1663, Irish inhabitants are recorded in New France. In the entire first phase of migration, perhaps as many as 400,000 people were transported to the British

45 H. McD. Beckles, "A 'Riotous and Unruly Lot": Irish Indentured Servants and Freeman in the English West Indies, 1644-1713', William and Mary Quarterly 47 (1990), 503.

46 M. Lamotte, 'Colour Prejudice in the Early Modern French Empire, c.1635-1767', unpublished $\mathrm{PhD}$ dissertation, University of Cambridge (2015). 
American colonies, amongst them many Irish migrants. Chartered companies recruited labourers for plantation settlements where cash crops including cotton, sugar and tobacco were cultivated for market. Of the total number who crossed the Atlantic from Ireland and Britain before 1680, over one-half went to the Caribbean islands, 120,000 to the Chesapeake and another 20,000 went to New England. More than 75 per cent of the total were indentured servants, most were under the age of twenty-five and most were from the lowest socio-economic sector of society. Migrants into English and British colonies were typically unskilled, semi-skilled or servant women. ${ }^{47}$ Migrants commonly travelled with relatives and many emigrants retained kinship connections and communitarian practices in the New World. Unmarried men, who made up the bulk of all European migrants in the pre-eighteenthcentury period, had the greatest opportunity. Because women had traditionally left home only to marry or to carry out service in prearranged locations, in this period few women - other than servants - moved alone to the Atlantic colonies. Very few Irish migrants could afford their own passage or could establish themselves as planters or merchants. On arrival, Irish migrants like all others faced a hostile disease environment (especially in the Chesapeake and the Caribbean), and mortality rates were as high as 40 per cent in the years immediately after arrival. ${ }^{48}$ Population growth was impeded in these first decades by the disproportionate sex ratio; by the 1660s, men outnumbered women by three to one in the Chesapeake. ${ }^{49}$ By the late 1670 s, more Irish and Scots migrants moved to the Chesapeake and Caribbean colonies and more African slaves were transported - as it grew more difficult to attract English migrants because of the harsh environment.

The Caribbean islands were the most favoured destination in the pre-1660 period; at this time 40 per cent of all colonists in the English American colonies lived in the Caribbean. In the 1650s, emigrants from Ireland rounded up after the Cromwellian campaigns in Drogheda and Dundalk added to the number. Barbados and Jamaica continued to attract large numbers of settlers and the Irish presence became significant on several islands; the change from

47 J. Horn, 'Tobacco Colonies: The Shaping of English Society in the Seventeenth-century Chesapeake', in N. Canny (ed.), The Oxford History of the British Empire, $i$ : The Origins of Empire: British Overseas Expansion to the Close of the Seventeenth Century (Oxford University Press, 1998), 176-7.

$48 \mathrm{~J}$. Horn, Adapting to a New World: English Society in the Seventeenth-Century Chesapeake (Chapel Hill, NC: The University of North Carolina Press, 1994), 23-6; R. S. Dunn, Sugar and Slaves: The Rise of the Planter Class in the English West Indies, 1624-1713 (Chapel Hill, NC: The University of North Carolina Press, 1972).

49 Horn, 'Tobacco Colonies', 182-4. 
cotton and tobacco to sugar in the later seventeenth century, and from indentured labour to slave society over the course of two generations, meant that by 1700 the islands no longer proved as attractive to Irish labourers. Sugar cultivation altered the demographics of the Caribbean, and Irish migrants, like their English and Scottish counterparts, were more attracted to mainland, than to island, colonies.

In the second phase of emigration from Ireland, after 1680 and before the 1770 s, the most evident change from the preceding period was the staggering increase in the number of Irish migrants, both Catholic and Protestant, crossing the Atlantic. The number of English and Welsh migrants declined, dropping from 350,000 in the seventeenth century to 80,000 in the eighteenth..$^{50}$ At the same time, ten times more Scots and Scots-Irish immigrated to the Americas in the eighteenth than in the seventeenth century and at least three times more Irish migrants made the crossing in the pre-revolutionary period. ${ }^{51}$ Convicts, too, were transported..$^{52}$ More migrants arrived to populate Pennsylvania and the middle colonies, and moved southwards along the valleys of the Appalachian mountains. Eighteenth-century migrants were more likely than their seventeenth-century predecessors to travel in family or community groups, and were usually more skilled or better informed on how to establish a household once their indentures had expired. By the time emigration from Ireland to the Americas resumed after the Seven Years War, ships from Ireland and England were carrying more non-English migrants than English colonists, and Irish migrants were swelling the numbers. The English American colonies were demographically, culturally and linguistically less English than they had ever previously been.

It is difficult to ascertain exact numbers of migrants from Ireland in this period, but records of exceptional individual success, and ship records and reports of departures, offer a representative sample of forms and types of emigration to the Americas. Already in 1621, Daniel Gookin, a merchant from Carrigaline, Cork, led a party of Irish settlers to Newport News, Virginia, on board the Flying Harte. Gookin's non-conformist son, Daniel the Younger, would go on to be a member of the governor's council of Massachusetts, representing Cambridge, and superintendent of Indian affairs. In the 1630s,

50 J. Horn, 'British Diaspora: Emigration from Britain, 1680-1815’, in P. J. Marshall (ed.), The Oxford History of the British Empire, ii: The Eighteenth Century (Oxford University Press, 1998), 30-2.

51 Horn, 'British Diaspora', 30-2.

52 A. R. Ekirch, Bound for America: The Transportation of British Convicts to the Colonies, 17181775 (Oxford University Press, 1987), 112-15. 
religious tolerance in Maryland encouraged a number of Irish Catholics to emigrate to the commonwealth, joining the significant English Catholic community. After the Test Acts of the 1670s and the subsequent fall of the Stuarts however, Catholic Irish migration was both discouraged and unwanted; occasional conformity favoured Presbyterians and Quakers from Ireland, if any non-Anglicans were at all to be permitted. In 1682, Thomas Dongan (16341715) became the first Irish Catholic governor of New York. Remembered most for the 'Charter of Libertyes and Privileges' ('Dongan's Charter'), Dongan convened the first representative assembly of New York Province on 4 October 1683, defining the form of government for the colony and recognising basic political and personal rights. Dongan was active in the same years as Charles Carroll, member of one of the most prosperous Irish families in North America at this time. Carroll became attorney general of Maryland in 1688; his grandson, Charles Carroll of Carrollton, was the only Catholic signatory to the Declaration of Independence. Maryland would not always remain so tolerant of Catholics; in 1704, laws were enacted to discourage the immigration and importation of Catholics.

Protestant Irish emigrants made up the greatest number of emigrants from Ireland by the early 1700s; by 1717, large-scale emigration from Ulster was in full flow and by 1775, as many as a quarter of a million Ulster-Scots had left Ireland for North America. From the early 1680s, outbreaks of disease and violence in Ulster and a severe winter in 1683-1684 threatened the pastoral economic base of the north of the country. Some Presbyterian dissenters, in County Tyrone, in early 1684 (prompted by the introduction of official measures against Presbyterian worship), were brought to conform, but 'others threaten to go to Carolina. Thither, I believe, some may go, but the noise of it is chiefly raised by such as think to make their landlords more indulgent to them from the apprehension of having their lands laid waste. We have had a very hard winter. ${ }^{53}$ In the same year a number of ministers from the suppressed Laggan Presbytery announced their intention to emigrate, citing not only 'persecutions' and the lack of access to their ministry but also the 'general poverty abounding in these parts'. ${ }^{54}$ In 1703 a proposal was made to transport a colony of 500 'inhabitants about Belfast, many of

53 Historical Manuscripts Commission, Calendar of the Manuscripts of the Marquess of Ormonde (new series, 8 vols., London: HMSO, 1902-1920), vii, 181; after G. Kirkham, 'Ulster Emigration to North America, $1680-1720$ ', in H. T. Blethen and C. W. Wood Jr (eds.), Ulster and North America. Transatlantic Perspectives on the Scotch-Irish (Tuscaloosa and London, The University of Alabama Press, 1997), 77

54 A. G. Lecky, The Laggan and its Presbyterianism (Belfast: Davidson and McCormack, 1905), reprinted as Roots of Presbyterianism in Donegal (Omagh: Graham and Sons, 1978), 18. 
them farmers of some substance' to Virginia or Maryland; the colonies were known because of ties with previous migrants to the region. ${ }^{55}$

Ulster ports continued to trade across the Atlantic throughout the War of Spanish Succession (1701-1714) and customs records show exports to the 'plantations' in every year from Belfast and Derry, as well as occasional ventures from other northern ports, including Donaghadee, Dundalk (including Newry), Killybegs (including Ballyshannon) and Sligo. ${ }^{56}$ There are few references to shipping arrivals from Ireland in the American press during the war, and it seems likely that much of this trade was with the West Indies or to the Chesapeake, for which newspaper coverage of maritime activity was poor and so shipping ventures continued largely unabated. There were few Irish migrants in this time: a small number of Quakers arrived in Philadelphia and a group of Donegal Presbyterians settled at Newcastle on the Delaware in 1706; another small migration took place to New England. The risks of travel in wartime and relatively good harvests in the first decade of the eighteenth century dissuaded greater migration; Britain effectively withdrew from the war in 1711 and the number of emigrant voyages once again picked up.

In the period 1713-1726, ten voyages to Virginia and Maryland from Irish ports outside Ulster are recorded, with four recording their cargo as servants and passengers; other Irish emigrants made their way to Virginia from Liverpool and other English ports. ${ }^{57}$ Even more migrants left in these years for the Caribbean and 1717 witnessed the great surge in emigration from Ireland. 'Last year some thousands of families are gone to the West Indies', wrote Archbishop King in early 1718 and although he likely exaggerated the size of the movement, and erroneously recorded the destination of the migrants (most, in fact, went to mainland American colonies), numbers did increase. In 1717 alone, twelve ships left Irish ports for America. One, the Friends Goodwill arrived in Boston in September 1717 direct from Dublin (although it may have briefly dropped anchor at Larne); the vessel had endured a horrifically long crossing of some eighteen weeks and the fifty-two crew, passengers and servants aboard were close to their end when they reached New England. ${ }^{58}$

Of the 'Scots-Irish' Ulster migrants, most came from Antrim, Derry, Donegal and Tyrone at this time, but not just: others came from Down,

55 C. Hedlam (ed.), Calendar of State Papers, Colonial Series: America and the West Indies, Dec. 1, 1702-1703 (London: HMSO, 1913), 263, 269-70.

56 'Ledgers of Imports and Exports of Ireland', CUST 15, The National Archives; Kirkham, 'Ulster Emigration to North America', 76-97, 79.

57 Kirkham, 'Ulster Emigration to North America', 76-97, 80.

58 Dickinson to John Askew, 24 October 1717, Letterbook of Jonathan Dickinson, Library Company of Philadelphia (held at the Historical Society of Pennsylvania). 
Fermanagh, Monaghan and from neighbouring Sligo, too. 'Nor do only Dissenters leave us, but proportionally of all sorts, except Papists', King wrote in June 1719. Driven out by increased rents: 'one reason they give for their going is the raising of the rent of the land to such a high rate that they cannot support their families thereon with the greatest industry'. ${ }^{59}$ 'Tithes, too, played a part in encouraging emigration.

In 1716 , legislation enacted by the South Carolina assembly to encourage the immigration of white indentured servants and to promote settlement on the frontier was publicised in Ireland. It included a package of measures, including 300 acres of land for each male settler of military age. ${ }^{60}$ In New England, too, moves to entice settlers to the undeveloped lands of various proprietors and to defend the frontier grew from c.1714. ${ }^{61}$ Advertisements for passage from Dublin to Boston appeared in Dublin newspapers throughout this period. After 1720, and primarily because of its increasing trade with Ulster and its religious tolerance, Pennsylvania became the primary destination of Irish Protestant immigrants. Gradually moving from the southwest further westward towards the frontier, they reached the backcountry in the south with Georgia. The growing influence of Irish Presbyterians in Philadelphia and Boston was well noted, as was the growing number of poor and destitute Irish arriving in these ports. On St Patrick's Day 1737, in Boston, twenty-six Irishmen founded the Charitable Irish Society, the oldest Irish society in North America, to address the growing crisis faced by the city in dealing with impoverished migrants arriving in the months from March to October every year. Irish men and women became a significant body of labourers in the North American colonies, most spending a period of time in indenture, and many running away from it as many advertisements in colonial broadsheets bear witness:

RUN away on the 27th of April past, at Night, from Samuel Butt of Plumsted Township, Bucks County, an Irish Servant Man, named William Cough [Cuugh], short of Stature, bow legged, flat footed, of a dark Complexion, round and full fac'd, much mark'd with the Small Pox, is watry eyed, and wears a Cap or light colour'd Wig: Had a good Felt Hat, a blue Duroy Coat lin'd with Silk Crape, a pretty good white Dimmity Jacket, and new Breeches of the same, a new fine Shirt and two new

59 Joseph Marriott, August 12, 1718, quoted in R. J. Dickson, Ulster Emigration to Colonial America, 1718-1775 (New York: Humanities Press, 1966), 29.

60 R. L. Meriweather, The Expansion of South Carolina, 1729-1765 (Kingsport, TN: Southern Publishers, 1940; repr. Philadelphia: Porcupine Press, 1974), 17.

61 R. H. Akagi, The Town Proprietors of the New England Colonies (Philadelphia: University of Pennsylvania Press, 1924; repr. Gloucester, MA: Peter Smith, 1963), 256-62. 
homepsun ones, two new Muslin Stocks, white Cotton Stockings and a pair of grey yarn ones, old round toe'd Shoes with strings in them. He has taken his own and another Man's Indentures with him. Whoever takes up and secures the said Servant, so that his Master may have him again, shall have Forty Shillings Reward, and reasonable Charges, paid by SAMUEL BUTT. $^{62}$

\section{Religious Confessionalism, Patria and Nation}

Ireland, home to a predominantly Catholic population and a succession of Protestant colonisation schemes, was but one of the many vigorously contested territories in the Atlantic world between Catholic and Protestant interests. ${ }^{63}$ When in the late eighteenth century, Edmund Burke deplored the assimilation of Protestants in general into a 'master caste', monopolising 'every franchise, every honour, every trust, every place down to the very lowest and least confidential', he signalled that religion had assumed central importance: no longer merely one badge of privilege. ${ }^{64}$ Confessional identity made a difference, without question, when deciding where one might settle and where one could gain refuge, but sectarianism was less blunt in the Atlantic colonies than it regularly was in Ireland at this time. Irish migrants lived and worked in Catholic and Protestant territories and, while not always by choice, Catholic Irish did not flee to a Catholic colony at first chance.

In Ireland, on the one hand, the 'Old English' discarded a sense of ethnic kinship with England in the course of the seventeenth century and its Catholic community assimilated to an indigenous Irish identity. New English settlers, on the other hand, remained a colonial nation with a stronger sense of nación and correspondingly weaker sense of Irish patria. This near-creole identity, intellectually justified in the writings of James Ussher, amongst others, sought to establish an indigenous pedigree for Irish Protestantism, removing it from the tainted legacy of English colonialism. ${ }^{65}$ Irish Catholic migrants had a greater sense of coming from and belonging to a patria than possessing a sense of nación. Only after this period would these relative investments slip and be inverted.

62 Pennsylvania Gazette, 11 May 1738.

63 J. Ohlmeyer, 'A Laboratory for Empire: Early Modern Ireland and English Imperialism', in K. Kenny (ed.), Ireland and the British Empire (Oxford University Press, 2006), 26-60.

64 Edmund Burke, 'A letter to Sir Hercules Langrishe' (1792) in The Works of the Right Honourable Edmund Burke (12 vols., London: John C. Nimmo, 1887), iv, 252.

65 Kidd, British Identities before Nationalism, 180-1. 
Diversity and interconnectedness of Protestantism around the Atlantic also produced conflicts within denominations, and in the case of migrants from Ireland, especially in the relations between Anglicans, Presbyterians and Quakers. From the 1730s, religious revivals, collectively labelled as the 'Great Awakening', crossed the sea, with historians uncovering evidence of interrelated sets of revivals in Ireland, Britain, the Americas and elsewhere, revealing deep disagreements about what it meant to be a Protestant and, in some contexts, what it meant to be Irish. ${ }^{66}$

In the Spanish Caribbean and on mainland Spanish colonies, Catholic practice eased entry into the highest branches of office. Alexander O'Reilly, for example, born in Baltrasna, County Meath, in 1722, helped to build fortresses in Havana and Puerto Rico and went on to be governor of Louisiana and Cuba. Like clerics, soldiers of Irish birth and ancestry were found throughout the Atlantic world. Not all remained loyal to Rome and success in the Caribbean turned many Irish Catholics into Protestants. Edmond Kelly, of Lisaduff, County Galway, became attorney general of Jamaica in the 1720s and in the 1740s Denis Kelly 'Jamaica Kelly' - was appointed chief justice. The family owned an estate that ran from the north to the south of the island. Kelly's daughter and heiress, Elizabeth, married into the once-Catholic, now Protestant, Browne family of Westport, County Mayo, in 1752 and with Elizabeth's wealth, the Brownes became Ireland's premier absentee plantation owners in the British Caribbean. ${ }^{67}$

Other Irish families traded on, and with, the Dutch and Danish islands of St Eustatius and Saint Croix. The sugar trade filled the coffers of Montserratian families including the Bodkins, Blakes and Brownes, the Kirwans, Skerrets and Ryans, making it seem like a tribes-of-Galway commercial venture. The Montserrat-born Nicholas Tuite (1705-1772), 'an English planter' for London eyes, was an Irishman for the Danes when the king of Denmark bestowed Danish citizenship on him in 1760. Irish identity, based on shared faith and historical experience, had evolved into a West Indian colonial identity. ${ }^{68}$ In England, and especially amongst English Catholics, they were particularly well received and in London and Bath they were hosted and feted. Irish Catholics married into English Catholic families, and while their Irish identity was forgotten, their Catholicism was maintained.

The Irish appeared early in the Caribbean, but their failure to found a colony meant that their history was rarely considered part of the official

66 S. O’Brien, 'A Transatlantic Community of Saints: The Great Awakening and the First

Evangelical Network, 1735-1755', American Historical Review, 91 (1986), 811-32.

67 N. Rodgers, 'A Changing Presence', 24.

68 N. Rodgers, 'A Changing Presence', 26. 
account. Working within others' empires, they left behind no distinctive state structure, language or architectural style, as other Europeans did. They were largely shut out by the Spanish, used by the French as allies when convenient, and treated as second-class subjects by the British; assimilation into these dominant groups increasingly became the only strategic possibility. They did, however, play an important part in turning the Leewards and Barbados into tobacco colonies, helped to prevent the Cromwellian conquest of Hispaniola, and applied their expertise to the development of Jamaica as a sugar island. In all these ventures, the Irish could be found in every social group, from indentured servant to slave and plantation owner.

\section{A ‘Green’ Atlantic?}

Ireland and the Atlantic world before the mid-eighteenth century was a very different iteration of the green Atlantic of the nineteenth century and thereafter. The ethno-religious identity of Irish migrants in the Atlantic world after 1845 must be reassessed against the preceding Irish Atlantic.

Historians of the Huguenot diaspora have recognised a wider, trans-Atlantic context of trade networks and familial links; a 'Protestant International' of trade, familial and scholarly networks superimposed over the Atlantic by the larger Protestant diaspora, of which the Huguenot migrations were a part. It was 'family relationships that formed the heart of the Protestant International'. ${ }^{69}$ Ireland and the Atlantic world pre-1750 is also of this model: networks enabled the maintenance of links of commonality with Irish communities around the Atlantic and in Europe. To substitute the word 'Irish' for 'Huguenot' in a line from Louis Cullen, demonstrates that these networks were 'not simply an offshoot of persecution, but a vital and ongoing part of the $\ldots$ activities of [the Irish overseas].$^{70}$ At least in the first generations in the Atlantic world, Irish emigrants were more like peninsulares (Spanish colonists) or the criollos of Cuba, spearheading and playing roles in others' colonial projects. Just as the criollos, over time, came to distance themselves from new Spanish colonists and a 'Spanish' identity, the Irish in the Atlantic world transformed, developing a worldview at odds with the majority population

69 For a discussion of this 'Protestant International', see J. F. Boscher, 'Huguenot Merchants and the Protestant International in the Seventeenth Century', William and Mary Quarterly, third series, 52 (1995) 77-102.

70 L. Cullen 'The Huguenots from the Perspective of the Merchant Networks of Western Europe 1680-1890: The Example of the Brandy Trade', in C. E. J. Caldicott, H. Gough and J. P. Pittion (eds.), The Huguenots in Ireland: Anatomy of an Emigration (Dun Laoghaire: Glendale, 1987), 129-49. 
around them. Underpinning that social framework were men who bore Irish surnames and were imbued with ambition, foot soldiers of empire in diverse projects of empire building. In the vanguard came cash-strapped members of a landed gentry from Ireland -perhaps not self-identifying as Irish per se, but from the island - vying for colonial governorships to pay off debts and support their lifestyles. And the majority were the poor sort, men and women from Ireland who moved, or were removed, out of need and persecution and who sought a new, improved, life overseas.

In the contentious matter of 'Irishness' in this period, for the vast majority of Irish people in the Atlantic world, Irish identity was protean, unlike the fixed, confessionalised, status of identity that limited the Irish in Ireland. The community of Irish Catholic planters of Montserrat, the island frequently presented as a model for how the Irish might (just) have run an Atlantic empire, was, to paraphrase Voltaire, neither Holy, nor Roman, nor an empire: they held slaves, did not suffer the same economic disabilities as Catholics in Ireland, and if theirs was an empire, it was a British, not an Irish, one, turning as they did to London to acquire houses and marry off their children and have them accepted into the metropolitan world. Amidst the ebb and flow of Irish migrants around the Atlantic flow, it is sure only that the pre-eighteenth century 'Irish International' in the Atlantic world helped to enable the mass emigration of the nineteenth century. 